\title{
Quantitative analysis of soft-bottom polychaetes of the Bellingshausen Sea and Gerlache Strait (Antarctica)
}

\author{
J. Parapar; E. López; M. C. Gambi; J. Núñez; A. Ramos
}

1. Departamento de Bioloxía Animal, Facultade de Ciencias, Universidade da Coruña, A Coruña, Spain

2. Laboratorio de Biología Marina e Invertebrados, Departamento de Biología, Facultad de Ciencias, Universidad Autónoma de Madrid, Madrid, Spain

3. Laboratorio di Ecologia del Benthos, Stazione Zoologica 'A. Dohrn, 'Ischia, Naples, Italy

4. Departamento de Biología Animal, Universidad de La Laguna, La Laguna, Tenerife, Islas Canarias, Spain

5. IEO Centro Oceanográfico de Vigo, Vigo, Spain

Polar Biology, May 2011, Volume 34, Issue 5, pp 715-730

Received: 9 September 2009 / Revised: 16 March 2010 / Accepted: 17 March 2010 / Published online: 2 December 2010

Cite this article as:

Parapar, J., López, E., Gambi, M.C. et al. Polar Biol (2011) 34: 715. doi:10.1007/s00300-0100927-4

The final publication is available at Springer via http://dx.doi.org/10.1007/s00300-010-0927-4

\begin{abstract}
The basin off the Bellingshausen Sea, in contrast to other better known areas such as the Antarctic Peninsula and the Ross and Weddell Seas, has been little investigated due to remoteness and the prevalence of ice for most of the year. The present study focuses on an analysis of polychaetes collected from soft bottoms of this sea and off the west coast of the Antarctic Peninsula (Gerlache Strait) by means of a box-corer $(25 \times 25 \mathrm{~cm})$ in two intensive surveys carried out during austral summers of 2002-2003 and 2005-2006 (BENTART-03 and BENTART-06). Three different polychaete assemblages were determined from the classification and ordination analyses of sampling stations based on the Bray-Curtis similarity index. One group of stations encompassed the deep stations from the shelf of the Bellingshausen Sea, the second one the shallower stations from the same area and the third one those stations located near the coast of Peter I Island and Gerlache Strait, off the Antarctic Peninsula. The environmental variables involved in segregating these groups were several sedimentary features (redox potential, gravel content) and depth. The present study provides further support to previous ones that considered the shelf of the Bellingshausen Sea as a differentiated region within the Southern Ocean, clearly distinct to the adjacent Weddell and Scott Seas and the Antarctic Peninsula.
\end{abstract}

\section{Keywords}

Polychaetes; Soft bottoms; Benthos; Box-corer; Distribution; BENTART cruises; Antarctica 


\section{Introduction}

Factors determining composition and spatial distribution of marine soft-bottom communities are numerous and acting at different spatial scales. The sediment characteristics (e.g., chlorophyll a content, sorting coefficient and organic matter content) are among those factors (Gray 1974), as the relationship between sediment and fauna constitutes a crucial aspect explaining the benthic ecology (Rhoads 1974) also in soft-bottom polar habitats (Gerdes et al. 1992). Other factors thought to be important as structuring agents of Antarctic benthic assemblages are hydrodynamics (Wu et al. 1992a, b), primary production in surface waters (Arrigo et al. 1998), flow of organic matter from the pelagic realm to the seabed (Grebmeier and Barry 1991) and iceberg scouring (Gutt and Starmans 1998, 2001; Gutt 2000, 2001; Gutt and Piepenburg 2003), the latter being particularly important in shallow water communities (Smale et al. 2007; Smale 2008a, b).

The Bellingshausen Sea represents a very interesting Antarctic area because it constitutes a natural connection between the Ross Sea and the Antarctic Peninsula; this area also has high zoogeographical importance because of its role in the dispersion of species around the waters of the Antarctic continent and South America through the Scotia Arc (Saiz et al. 2008). Due to its remoteness and the prevalence of ice during most of the year, the Bellingshausen Sea was much less visited by research vessels and less studied compared to the Weddell and Ross Seas or the Antarctic Peninsula, where many countries have carried out vast research programs in past decades (e.g., Arntz et al. 1994; Guglielmo et al. 2000; Brandt et al. 2004).

Polychaetes are one of the most relevant components of Antarctic soft-bottom macrobenthic assemblages (Arnaud 1974; Knox 2007) contributing substantially to the benthic community both in terms of abundance and biomass (e.g., Gerdes et al. 1992; Saiz-Salinas et al. 1997; Piepenburg et al. 2002). Only little and scarce information on the composition and structure of the polychaete fauna of the Bellingshausen Sea is yet available, whereas more information exists about these organisms in other parts of Antarctica (e.g., Hartmann-Schröder and Rosenfeldt 1988, 1989, 1990, 1991, 1992; Cantone et al. 2000; Cantone and di Pietro 2001; Hilbig 2001, 2004; Hilbig et al. 2006; Schüller and Ebbe 2007; Schüller and Hilbig 2007; Schüller 2008a; Schüller et al. 2009). Past data derive mainly from European cruises done in the first half of the twentieth century (Augener 1932; Fauvel 1936) and more recent US American expeditions (Hartman 1952, 1967; Maciolek and Blake 2006).

The present study draws upon the polychaete material collected in two intensive surveys conducted off the north-west coast of the Antarctic continent in the frame of the Spanish BENTART-03 and BENTART-06 cruises. The study of the polychaete collections obtained from two previous cruises to the Antarctic Peninsula, namely BENTART-94 and BENTART-95, was already published by Parapar and San Martín (1997), San Martín and Parapar (1997) and San Martín et al. (2000).

The aim of this work is to analyse the species composition, abundance and distribution of the polychaete fauna in the shelf and slope of the Bellingshausen Sea and adjacent areas in order to characterize their assemblages present on the sea floor, to identify the environmental factors that may affect and/or determine the distribution of the species and to compare our results with those available on other groups in the same area, either benthic or suprabenthic, such as molluscs (Troncoso et al. 2007; Troncoso and Aldea 2008), fishes (Matallanas and Olaso 2007) and cumaceans (Corbera et al. 2009), and with the whole collected infauna and suprabenthos studied at higher taxonomic level (Saiz et al. 2008; San Vicente et al. 2009). 


\section{Materials and methods}

Study area and sample collection

The material analysed in this study was obtained during the Spanish oceanographic cruises BENTART-03 (24 January to 3 March 2003) and BENTART-06 (2 January to 17 February 2006) on board the R/V Hespérides. Samples were collected from 40 stations distributed along the NW sector of the Antarctic Ocean, from the Antarctic Peninsula (mainly from Gerlache Strait) (AP) to the Thurston Island in the Bellingshausen Sea (BS) and the proximity of the Peter I Island (PI) (Fig. 1). Benthic polychaetes from the soft bottoms were collected by different sampling gears (Agassiz trawl, Suprabenthic sledge and box-corer) but only the material taken with the USNEL-type box-corer (BC) with a maximum breakthrough of $60 \mathrm{~cm}$ and an effective surface of sampling of $25 \times 25 \mathrm{~cm}$ was considered for the present work. When possible, two duplicate samples per station were collected. Each BC sample was subdivided into four equal sub-samples of $0.063 \mathrm{~m}^{2}$. The first sub-sample was immediately used on board to measure redox (Eh) and later to analyse sediment grain size and content of carbonates and organic matter. The three remaining sub-samples (or one coming from the first $\mathrm{BC}$ and two equivalent sub-samples from the second $\mathrm{BC}$ if two samples were collected at the station) were used for quantitative assessment of the fauna. For this purpose, the collected sediment was sieved through three mesh sizes $(5,1$ and $0.5 \mathrm{~mm})$; the polychaetes collected in the two larger sieves were counted on board to estimate their relative abundance within the total macrobenthic fauna collected. Then, all the specimens were fixed on board in a buffered $4 \%$ formaldehyde seawater solution and afterwards preserved in $70 \%$ ethanol. More detailed description of sampling gear, sampling method and sediment abiotic variables analysis can be found in Saiz et al. (2008).

The use of the box-corer and its effectiveness in sampling were limited by weather conditions; for this reason, only 30 stations were sampled with this gear, 28 of which provided polychaete specimens. The geographical positions of the stations are reported in Fig. 1, and their location and depth (ranging from 90 to 3,304 m), as well as the studied environmental variables, are given in Table 1.

Data analysis

A species/abundance matrix was created, summarizing the actual number of individuals of each polychaete species present in each station, respectively, the sum of the three sub-samples. Statistical analysis was carried out using the PRIMER v5.0 (Plymouth Routines In Multivariate Ecological Research) software package (Clarke and Warwick 1994). Univariate measures were computed for each station: total abundance $(N)$, number of species $(S)$, Margalef diversity index $(d)$, ShannonWiener diversity index $\left(H^{\prime} \log _{\mathrm{e}}\right.$ based $)$ and Pielou's evenness $\left(J^{\prime}\right)$ based on Shannon-Wiener index. A second matrix was derived from the abundance matrix, showing the similarity between stations by means of the Bray-Curtis coefficient, after data have been log-transformed $(X=\log (x+1))$ to limit the influence of the most dominant species. From this matrix, a classification of the stations was performed by cluster analysis based on the group-average sorting algorithm. A non-metric MultiDimensional Scaling (nMDS) ordination was also performed based on the similarity matrix. The SIMPER (similarity percentage) application was used to identify species that contributed in higher proportion to the differentiation of station groups.

The BIO-ENV procedure was used to investigate the relationship between polychaete assemblages and the measured abiotic variables, although station AP39 was excluded from this analysis because of the lack of environmental data. All environmental variables were $\log (x+1)$ transformed previously to analysis. The variables considered were depth $(m)$, organic matter content $(\%)$ and percentage of 
each granulometric fraction (\%), whereas carbonates were discarded from the analysis because of the lack of data in a large number of stations. The assessment of the importance of the redox potential at the surface of the sediment posed a problem, since in stations BS14 and AP25 such data were missing. Thus, BIO-ENV procedure was carried out in a twofold way: first the application was run considering all the stations without the redox potential, and then it was re-run considering all the variables but eliminating stations BS14 and AP25. In order to check the stability of the groups obtained from cluster and nMDS, these analyses were re-computed without considering the two rejected stations.

The statistical level of significance of differences between groups regarding to mean values of faunistic and environmental parameters was checked by means of a non-parametric test (KruskalWallis), which was carried out using the SPSS v16.0 statistical package. The differences were considered significant when $P<0.05$.

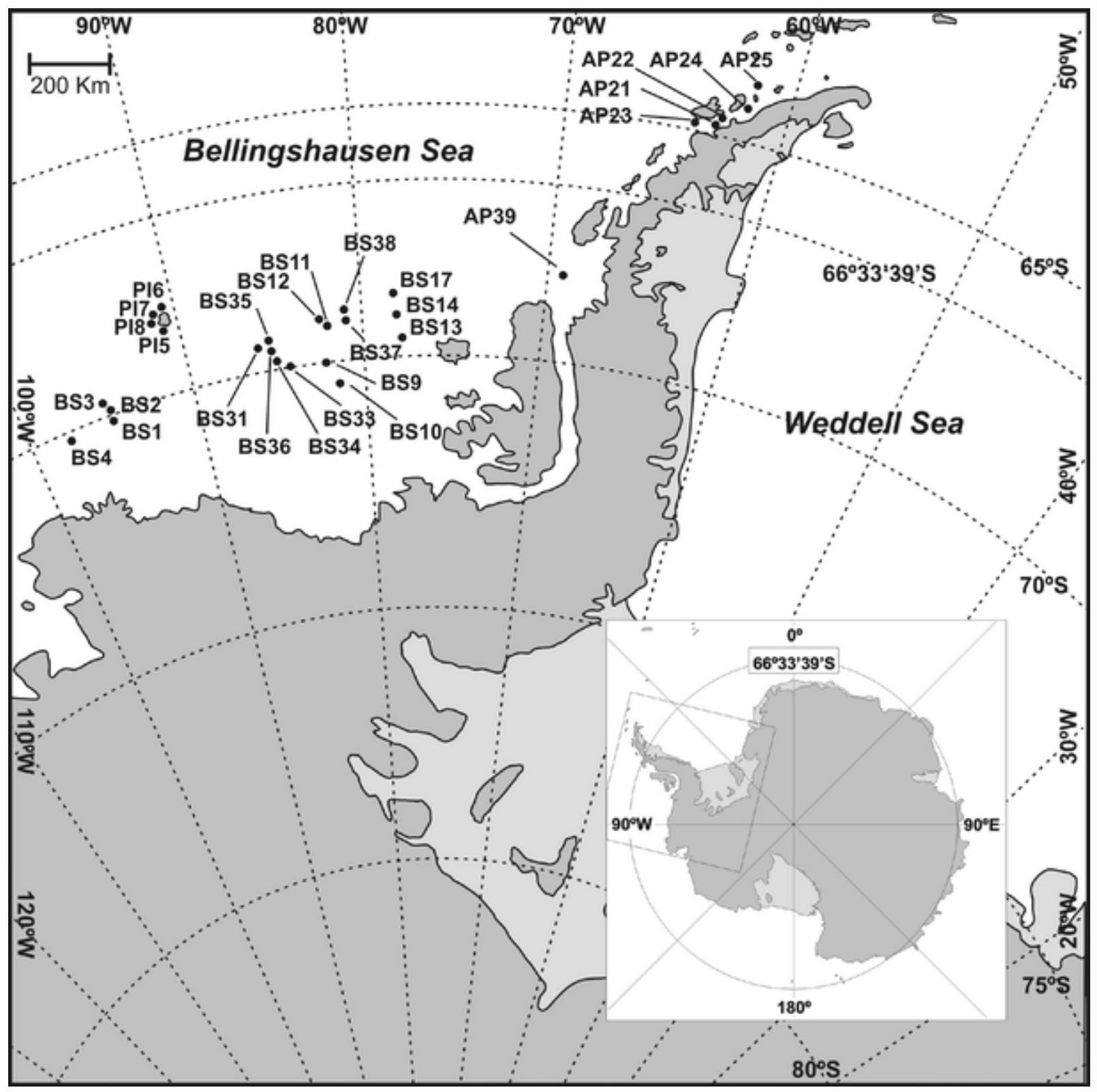

Fig. 1 Study area showing box-corer sampling stations surveyed during the BENTART-03 and BENTART-06 cruises with polychaete specimens. AP Antarctic Peninsula, BSBellingshausen Sea, PI Peter I Island 


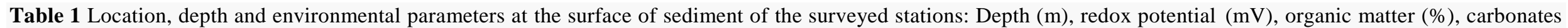
$(\%)$, gravel $(>2 \mathrm{~mm}, \%)$, coarse sand $(>0.5 \mathrm{~mm}, \%)$, medium sand $(>0.25 \mathrm{~mm}, \%)$, fine sand $(>0.0625 \mathrm{~mm}, \%)$ and mud $(<0.0625, \%)$

\begin{tabular}{|c|c|c|c|c|c|c|c|c|c|c|c|}
\hline Station & Latitude S & Longitude W & Depth & Redox & OM & Carbonates & Gravel & CS & MS & FS & $\mathrm{S}+\mathrm{C}$ \\
\hline BS1 & $70^{\circ} 38.22^{\prime}$ & $95^{\circ} 15.36^{\prime}$ & 534 & 252.2 & 4.81 & n.d. & 14.30 & 7.90 & 7.50 & 19.10 & 51.20 \\
\hline BS2 & $70^{\circ} 29.25^{\prime}$ & $95^{\circ} 14.83^{\prime}$ & 780 & 289.3 & 5.02 & n.d. & 81.40 & 1.80 & 1.10 & 4.20 & 11.50 \\
\hline BS3 & $70^{\circ} 17.58^{\prime}$ & $95^{\circ} 11.86^{\prime}$ & 1,431 & 259.8 & 5.42 & n.d. & 29.00 & 4.30 & 3.40 & 30.50 & 32.80 \\
\hline BS4 & $70^{\circ} 52.86^{\prime}$ & $98^{\circ} 26.12^{\prime}$ & 425 & 271.3 & 4.56 & n.d. & 31.00 & 9.60 & 5.40 & 16.40 & 37.60 \\
\hline PI5 & $68^{\circ} 56.70^{\prime}$ & $90^{\circ} 35.70^{\prime}$ & 126 & 199.3 & 1.43 & n.d. & 0.14 & 0.14 & 0.32 & 19.50 & 79.90 \\
\hline PI6 & $68^{\circ} 49.61^{\prime}$ & $90^{\circ} 48.78^{\prime}$ & 210 & 122.5 & 1.35 & n.d. & 0.00 & 0.10 & 0.10 & 21.00 & 78.80 \\
\hline PI7 & $68^{\circ} 42.20^{\prime}$ & $90^{\circ} 40.80^{\prime}$ & 410 & 174.8 & 1.85 & n.d. & 0.00 & 0.20 & 0.20 & 6.10 & 93.50 \\
\hline PI8 & $68^{\circ} 50.18^{\prime}$ & $90^{\circ} 51.08^{\prime}$ & 90 & 155.8 & 1.23 & n.d. & 0.10 & 0.80 & 4.90 & 58.90 & 35.30 \\
\hline BS9 & $70^{\circ} 14.40^{\prime}$ & $81^{\circ} 47.03^{\prime}$ & 532 & 261.8 & 5.96 & n.d. & 3.90 & 6.10 & 4.40 & 12.40 & 73.20 \\
\hline BS10 & $70^{\circ} 44.31^{\prime}$ & $81^{\circ} 27.85^{\prime}$ & 497 & 260.0 & 4.05 & n.d. & 15.80 & 5.20 & 7.90 & 16.40 & 54.70 \\
\hline BS11 & $69^{\circ} 27.07^{\prime}$ & $82^{\circ} 06.76^{\prime}$ & 1,289 & 266.0 & 3.81 & n.d. & 22.40 & 8.50 & 3.70 & 10.60 & 54.80 \\
\hline BS12 & $69^{\circ} 24.27^{\prime}$ & $82^{\circ} 11.88^{\prime}$ & 2,032 & 261.5 & 5.29 & n.d. & 23.00 & 11.10 & 5.80 & 18.06 & 42.04 \\
\hline BS13 & $69^{\circ} 49.56^{\prime}$ & $77^{\circ} 43.68^{\prime}$ & 605 & 240.5 & 4.64 & n.d. & 10.20 & 3.60 & 4.10 & 17.50 & 64.60 \\
\hline BS14 & $69^{\circ} 21.12^{\prime}$ & $78^{\circ} 04.91^{\prime}$ & 498 & n.d & 3.68 & n.d. & 34.70 & 5.10 & 3.80 & 11.70 & 44.70 \\
\hline BS17 & $68^{\circ} 54.88^{\prime}$ & $78^{\circ} 14.16^{\prime}$ & 2,044 & 224.7 & 1.98 & n.d. & 64.50 & 18.60 & 3.90 & 2.90 & 10.10 \\
\hline AP21 & $64^{\circ} 54.01^{\prime}$ & $63^{\circ} 01.11^{\prime}$ & 107 & 133.5 & 2.49 & n.d. & 4.40 & 14.80 & 17.90 & 34.80 & 28.10 \\
\hline AP22 & $64^{\circ} 50.58^{\prime}$ & $62^{\circ} 57.91^{\prime}$ & 294 & 137.0 & 6.40 & n.d. & 0.00 & 0.00 & 0.30 & 3.20 & 96.50 \\
\hline AP23 & $64^{\circ} 55.95^{\prime}$ & $63^{\circ} 38.40^{\prime}$ & 655 & 272.5 & 6.75 & n.d. & 0.00 & 0.50 & 0.50 & 7.10 & 91.90 \\
\hline AP24 & $64^{\circ} 20.11^{\prime}$ & $61^{\circ} 58.82^{\prime}$ & 1,056 & 170.5 & 8.32 & n.d. & 0.00 & 0.24 & 0.23 & 1.63 & 98.00 \\
\hline AP25 & $63^{\circ} 52.85^{\prime}$ & $61^{\circ} 48.52^{\prime}$ & 110 & n.d. & 1.16 & n.d. & 23.80 & 22.90 & 13.50 & 36.30 & 3.50 \\
\hline BS31 & $69^{\circ} 56.98^{\prime}$ & $86^{\circ} 19.27^{\prime}$ & 1,426 & 207.8 & 5.31 & 2.54 & 0.00 & 2.22 & 4.81 & 20.74 & 72.22 \\
\hline BS33 & $70^{\circ} 15.90^{\prime}$ & $84^{\circ} 11.45^{\prime}$ & 438 & 290.2 & 4.02 & 1.38 & 20.11 & 12.99 & 8.86 & 26.32 & 31.72 \\
\hline BS34 & $70^{\circ} 08.20^{\prime}$ & $84^{\circ} 51.68^{\prime}$ & 603 & 326.0 & 1.80 & 1.27 & 0.00 & 12.91 & 14.98 & 59.89 & 12.21 \\
\hline BS35 & $69^{\circ} 56.03^{\prime}$ & $85^{\circ} 11.30^{\prime}$ & 1,117 & 260.7 & 7.36 & 2.40 & 47.65 & 3.78 & 1.73 & 9.13 & 37.72 \\
\hline BS36 & $69^{\circ} 56.28^{\prime}$ & $80^{\circ} 24.55^{\prime}$ & 560 & 289.0 & 8.51 & 0.47 & 33.15 & 1.08 & 1.08 & 3.96 & 60.72 \\
\hline BS37 & $69^{\circ} 26.38^{\prime}$ & $80^{\circ} 51.62^{\prime}$ & 495 & 244.0 & 5.70 & 0.64 & 35.37 & 17.04 & 10.27 & 16.16 & 21.27 \\
\hline BS38 & $69^{\circ} 14.08^{\prime}$ & $80^{\circ} 61.20^{\prime}$ & 1,324 & 298.2 & 5.98 & 0.83 & 65.69 & 3.14 & 1.26 & 2.72 & 27.20 \\
\hline AP39 & $68^{\circ} 07.78^{\prime}$ & $69^{\circ} 35.31^{\prime}$ & 167 & n.d. & n.d. & n.d. & n.d. & n.d. & n.d. & n.d. & n.d. \\
\hline
\end{tabular}

$C S$ Coarse sand, $M S$ Medium sand, FS Fine sand, $O M$ Organic matter, $S+C$ Silt and clay, $n . d$. Not determined 


\section{Results}

A total of 1,328 polychaete specimens were collected belonging to 28 families (Appendix). Seventyseven taxa were identified to species level; for the remaining 14 taxa, the systematic attribution was limited by the fact that the collected specimens were incomplete or badly damaged ("undet.") or belonged to poorly known genera or family that need a thorough revision to be properly classified (“sp.").

\section{Faunistic parameters}

The most diverse family in number of species was Maldanidae (7 species), followed by Spionidae and Terebellidae (6 species), while the best represented families in terms of abundance (number of individuals) were Maldanidae (344 specimens), Terebellidae (196) and Cirratulidae (162) with the maldanid Rhodine intermedia (182 individuals), the cirratulid Aphelochaeta cincinnata(120 individuals), the terebellid Pista spinifera (91 individuals) and the spionid Laonice antarcticae (86 individuals) being the most abundant species.

Number of species $(S)$, abundance $(N)$, diversity $\left(H^{\prime}\right)$ and evenness $\left(J^{\prime}\right)$ all varied widely in the studied area (Table 2). The variability among stations in terms of number of species and abundance showed strong differences according to geographical position (Fig. 2). Values of the samples from Peter I Island (PI) and Antarctic Peninsula (AP) were generally higher than those in the Bellingshausen Sea (BS), especially regarding the abundance. The number of polychaete individuals occurring in each station (Table 2) ranged from 2 (stations BS12, BS31, BS33 and BS35) to 296 (station AP21); in the same way, the species number showed its minimum (2) in the group of stations with lower abundances, whereas in station AP21, the highest number of species was achieved (44).

The values of diversity indexes (Table 2) paralleled those of species number. Both Margalef and Shannon-Wiener indexes were lowest in stations BS12, BS31, BS33 and BS35 $\left(d=1.44 ; H^{\prime}=0.69\right.$, respectively); maximum values were recorded in AP39 $\left(d=5.77 ; H^{\prime}=2.89\right)$ and AP21 $\left(d=7.56 ; H^{\prime}=2.97\right)$. Values for $J^{\prime}$ were usually higher than 0.6 , except for stations PI8 (0.48) and $\operatorname{AP} 23(0.55)$.

Polychaete assemblages and community structure

Three major groups of stations could be identified in the plot resulting from the cluster analysis (Fig. 3), although the similarity was low (below 20\%). Group A1 (similarity around 14.21\%) included most of the stations located within the Bellingshausen Sea, whereas BS4, BS9 and BS33 formed the group A2 that is a smaller cluster linked to the former at a low similarity value $(23.62 \%)$. Group B (similarity 17.81\%) included those stations located around Peter I Island or off the Antarctic Peninsula and Gerlache Strait. These three groups were also apparent in the nMDS analysis (Fig. 4a) based on Bray-Curtis similarity. The groups A1 and A2 were well defined and occupied the left half of the plot, whereas the group B appeared clearly segregated from them in the right half. There were differences among clusters in mean abundance and number of species per station. Thus, groups A1 and A2 have similarly low average numbers of individuals (mean \pm standard deviation; $7.69 \pm 5.30$ and $10.00 \pm 7.00$, respectively) and species $(5.77 \pm 3.27$ and $7.00 \pm 4.58)$ while the mean number of individuals $(118.40 \pm 5.30)$ and species $(18.20 \pm 10.54)$ was higher in group B; differences were statistically significant for these two parameters $(P=0.000$ for number of individuals and $P=0.001$ for number of species). Diversity values were consistently higher in stations of group B (average $d=3.61 \pm 1.85$, average $H^{\prime}=1.97 \pm 0.61$ ) than those in group A1 (average $d=2.38 \pm 0.80$; average $H^{\prime}=1.51 \pm 0.58$ ) and A2 (average $d=2.62 \pm 1.13$, average $H^{\prime}=1.67 \pm 0.87$ ); however, 
confidence levels were not enough to warrant statistical significance $(P=0.138$ for $d$ and $P=0.355$ for $\left.H^{\prime}\right)$.

Table 2 Ecological parameters at each station

\begin{tabular}{|c|c|c|c|c|c|}
\hline Station & $S$ & $N$ & $d$ & $H^{\prime}$ & $J^{\prime}$ \\
\hline BS1 & 5 & 5 & 2.49 & 1.61 & 1.00 \\
\hline BS2 & 3 & 3 & 1.82 & 1.10 & 1.00 \\
\hline BS3 & 9 & 10 & 3.47 & 2.16 & 0.98 \\
\hline BS4 & 7 & 8 & 2.89 & 1.91 & 0.98 \\
\hline PI5 & 15 & 88 & 3.13 & 2.09 & 0.77 \\
\hline PI6 & 14 & 118 & 2.72 & 1.79 & 0.68 \\
\hline PI7 & 18 & 87 & 3.81 & 2.04 & 0.71 \\
\hline PI8 & 22 & 176 & 4.06 & 1.48 & 0.48 \\
\hline BS9 & 5 & 6 & 2.23 & 1.56 & 0.97 \\
\hline BS10 & 7 & 11 & 2.50 & 1.77 & 0.91 \\
\hline BS11 & 8 & 13 & 2.73 & 1.93 & 0.93 \\
\hline BS12 & 2 & 2 & 1.44 & 0.69 & 1.00 \\
\hline BS13 & 6 & 9 & 2.28 & 1.58 & 0.88 \\
\hline BS14 & 13 & 20 & 4.01 & 2.42 & 0.94 \\
\hline BS17 & 4 & 5 & 1.86 & 1.33 & 0.96 \\
\hline AP21 & 44 & 296 & 7.56 & 2.97 & 0.78 \\
\hline AP22 & 9 & 70 & 1.88 & 1.48 & 0.67 \\
\hline AP23 & 14 & 135 & 2.65 & 1.45 & 0.55 \\
\hline AP24 & 7 & 94 & 1.32 & 1.22 & 0.63 \\
\hline AP25 & 14 & 56 & 3.23 & 2.31 & 0.88 \\
\hline BS31 & 2 & 2 & 1.44 & 0.69 & 1.00 \\
\hline BS33 & 2 & 2 & 1.44 & 0.69 & 1.00 \\
\hline BS34 & 11 & 15 & 3.69 & 2.34 & 0.98 \\
\hline BS35 & 2 & 2 & 1.44 & 0.69 & 1.00 \\
\hline BS36 & 8 & 13 & 2.73 & 1.99 & 0.96 \\
\hline BS37 & 8 & 10 & 3.04 & 2.03 & 0.97 \\
\hline BS38 & 6 & 8 & 2.40 & 1.67 & 0.93 \\
\hline AP39 & 25 & 64 & 5.77 & 2.89 & 0.90 \\
\hline
\end{tabular}

$S$ number of species, $N$ number of specimens collected in $1,875 \mathrm{~cm}^{2}, d$ Margalef diversity index, $H^{\prime}$ ShannonWiener diversity index, $\log _{\mathrm{e}}$ based, $J^{\prime}$ Pielou evenness index, based on $H^{\prime}$ 

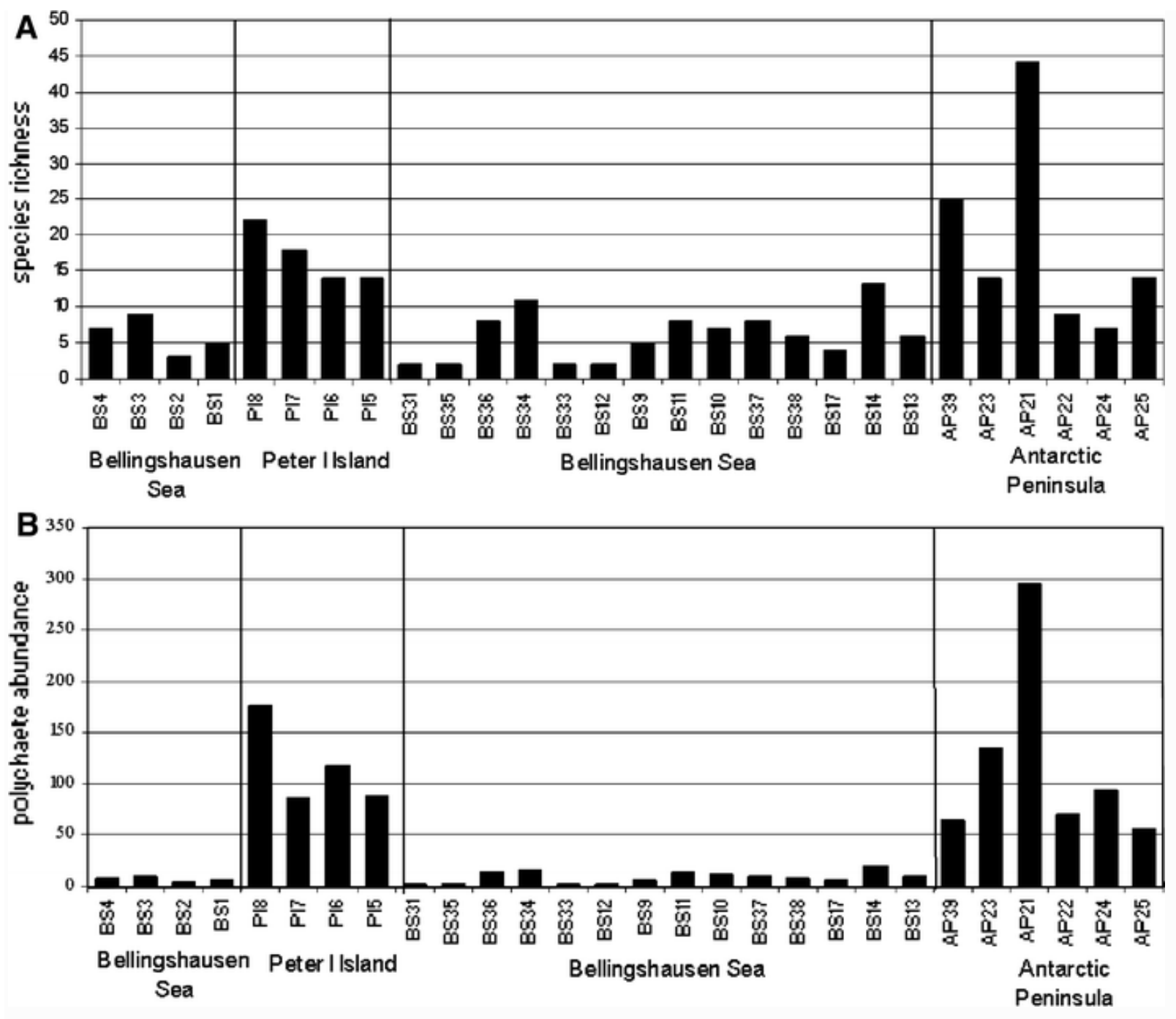

Fig. 2 Number of species (a) and abundance (b) of Polychaeta at each station; stations arranged according to geographical position from west to east

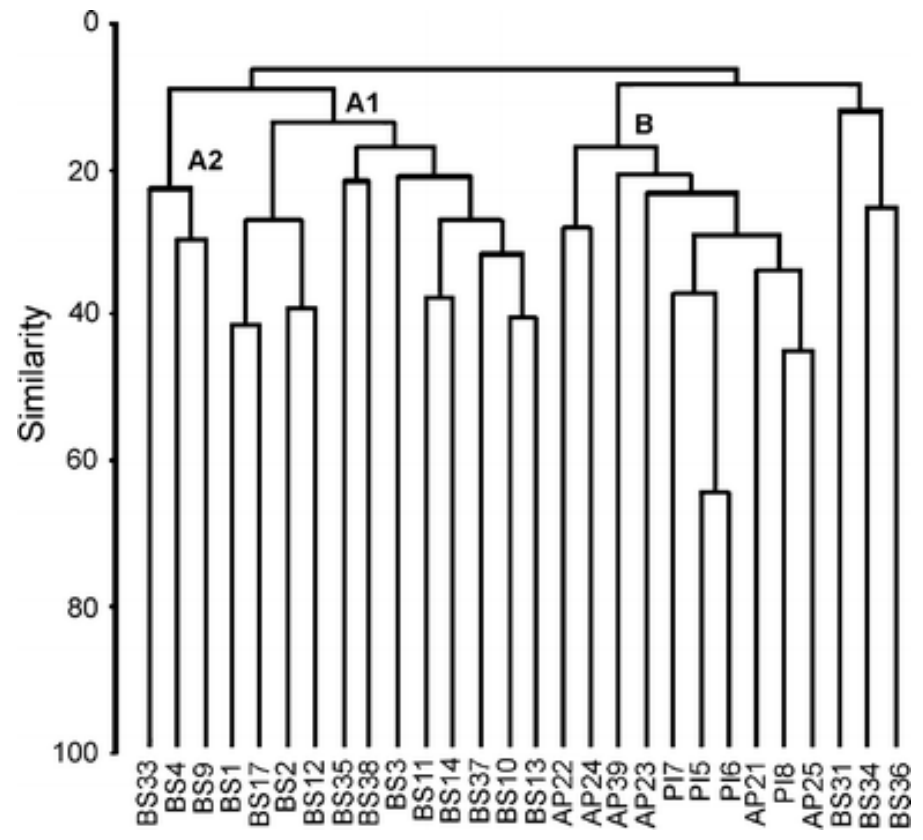

Fig. 3 Plot resulting from the cluster analysis of the similarity matrix obtained from the pairwise computing of the BrayCurtis index 
Internal similarities and differences in the faunistical composition of the defined assemblages were analysed by means of the SIMPER application (Tables 3, 4; Fig. 5). The group A1 (Bellingshausen Sea samples) was dominated by families Paraonidae, Maldanidae, Capitellidae and Opheliidae (Fig. 5) and characterized by proportionately higher abundances of the capitellid species Notomastus latericeus and the scalibregmatid Travisia abyssorum. The maldanid Maldane sarsi antarctica, the paraonid Aricidea (Allia) belgicae and the glycerid Glycera kerguelensis contributed to most of the cumulative similarity of the group (up to $86.67 \%$ ). In turn, the families that contributed most to group A2 were Paraonidae, Cirratulidae and Nephthyidae; this group was especially characterized by the paraonid species A. (A.) belgicae and the nephthyid Aglaophamus trissophyllus, with these two species accounting for $100 \%$ of cumulative similarity. In group B, the numerically dominant taxa were Maldanidae and Terebellidae. Many species contributed to the similarity within the assemblage (Table 3). Of these, only the lumbrinerid Lumbrineris kerguelensis contributed to more than $10 \%$ of cumulative similarity. The maldanid Rhodine intermedia accounted for $9.6 \%$ of similarity, and the maldanid $M$. sarsi antarctica, the cirratulid Aphelochaeta cincinnata, the spionid Laonice weddellia and the terebellid Pista spinifera contributed around 5\% each. However, the species more important when explaining the differences between the group B and groups A1 and A2 varied slightly from the former results (Table 4); those contributing to differentiate group B from A1 and A2 were the maldanid $R$. intermedia, the terebellid $P$. spinifera as well as the terebellid Artacama proboscidea and the spionid Laonice antarcticae.
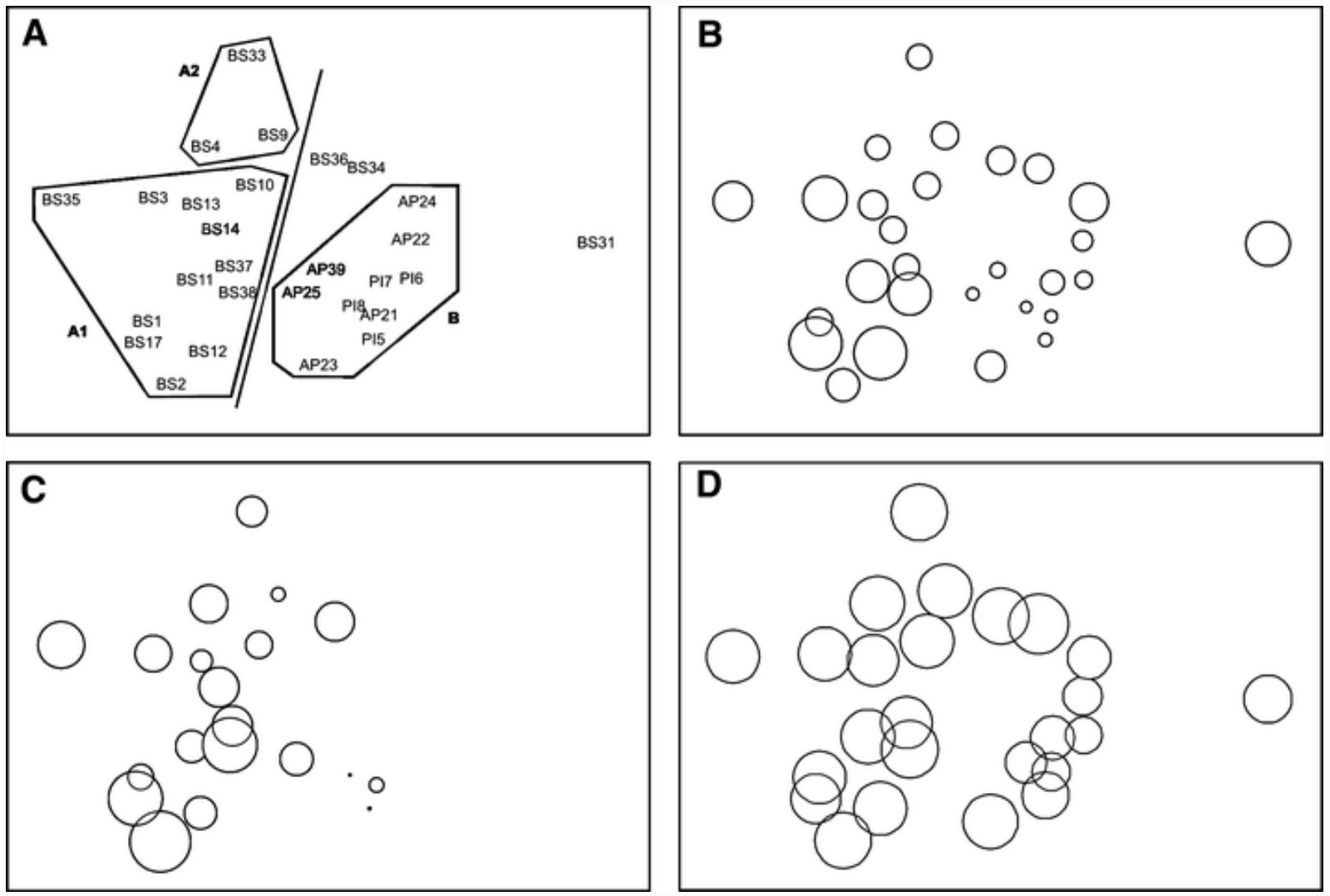

Fig. 4 a Plot resulting from the Multi-Dimensional Scaling analysis of the similarity matrix obtained from the pairwise computing of the Bray-Curtis index. The solid line indicates separation between the two main groups (shelf of the Bellingshausen vs. Antarctic Peninsula and Peter I Island). Stress: 0.18. b-d The same nMDS ordination of stations as in (a) showing superimposed values of variables selected by the BIO-ENV procedure. bdepth; c gravel; and $\mathbf{d}$ redox potential (Eh). Values of all environmental variables are not available for AP39; redox values for BS14 and AP25 were missing 
Table 3 Species contributing to the similarity of stations within the groups identified by the Bray-Curtis similarity analysis, as defined by SIMPER

\begin{tabular}{|c|c|c|c|c|c|}
\hline Species & AvAbnd & AvSim & $\mathrm{Sim} / \mathrm{SD}$ & Contrib\% & Cum\% \\
\hline \multicolumn{6}{|c|}{ Group A1 (Average similarity $=18.38$ ) } \\
\hline Notomastus latericeus & 1.18 & 8.01 & 0.83 & 43.58 & 43.58 \\
\hline Travisia abyssorum & 1.00 & 4.06 & 0.72 & 22.07 & 65.65 \\
\hline Maldane sarsi antarctica & 0.55 & 1.48 & 0.33 & 8.06 & 73.71 \\
\hline Aricidea (Allia) belgicae & 0.91 & 1.21 & 0.21 & 6.60 & 80.31 \\
\hline Glycera kerguelensis & 0.45 & 1.17 & 0.32 & 6.36 & 86.67 \\
\hline Phyllochaetopterus monroi & 0.36 & 0.93 & 0.34 & 5.07 & 91.75 \\
\hline \multicolumn{6}{|c|}{ Group A2 (Average similarity $=24.52)$} \\
\hline Aricidea (Allia) belgicae & 1.33 & 19.76 & 3.69 & 80.58 & 80.58 \\
\hline Aglaophamus trissophyllus & 0.67 & 4.76 & 0.58 & 19.42 & 100.00 \\
\hline \multicolumn{6}{|c|}{ Group B (Average similarity $=13.96)$} \\
\hline Lumbrineris kerguelensis & 6.40 & 3.39 & 1.35 & 24.28 & 24.28 \\
\hline Rhodine intermedia & 17.80 & 1.35 & 0.42 & 9.65 & 33.92 \\
\hline Maldane sarsi antarctica & 2.60 & 1.06 & 1.05 & 7.58 & 41.51 \\
\hline Aphelochaeta cincinnata & 11.90 & 1.04 & 0.48 & 7.48 & 48.99 \\
\hline Laonice weddellia & 3.00 & 0.92 & 0.45 & 6.62 & 55.61 \\
\hline Pista spinifera & 9.10 & 0.86 & 0.18 & 6.17 & 61.78 \\
\hline Maldanidae gen. sp. & 5.20 & 0.70 & 0.24 & 5.05 & 66.83 \\
\hline Amphicteis gunneri antarctica & 5.20 & 0.51 & 0.25 & 3.62 & 70.45 \\
\hline Notomastus latericeus & 2.10 & 0.48 & 0.59 & 3.44 & 73.89 \\
\hline Laonice antarcticae & 8.60 & 0.46 & 0.72 & 3.31 & 77.20 \\
\hline Eulalia subulifera & 1.50 & 0.46 & 0.59 & 3.28 & 80.48 \\
\hline Spiophanes tcherniai & 1.90 & 0.41 & 0.44 & 2.93 & 83.41 \\
\hline Euchone pallida & 1.70 & 0.34 & 0.49 & 2.46 & 85.87 \\
\hline Ophelina breviata & 2.10 & 0.27 & 0.37 & 1.93 & 87.80 \\
\hline Galathowenia scotiae & 1.60 & 0.27 & 0.32 & 1.91 & 89.71 \\
\hline Axiothella antarctica & 5.00 & 0.26 & 0.20 & 1.85 & 91.56 \\
\hline
\end{tabular}

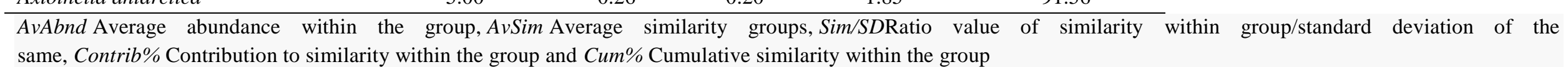


Table 4 Species contributing to the dissimilarity between the pairs of groups of stations identified by the Bray-Curtis similarity analysis, as defined by SIMPER

\begin{tabular}{|c|c|c|c|c|c|c|}
\hline Species & Group A1 AvAbnd & Group A2 AvAbnd & AvDiss & Diss/SD & Contrib\% & Cum\% \\
\hline \multicolumn{7}{|c|}{ A1 versus A2 (Average dissimilarity $=91.29)$} \\
\hline Aricidea (Allia) belgicae & 0.91 & 1.33 & 13.44 & 1.80 & 14.72 & 14.72 \\
\hline Notomastus latericeus & 1.18 & 0.00 & 8.88 & 1.32 & 9.73 & 24.44 \\
\hline Travisia abyssorum & 1.00 & 0.00 & 6.63 & 0.91 & 7.27 & 31.71 \\
\hline Aglaophamus trissophyllus & 0.09 & 0.67 & 4.87 & 1.15 & 5.33 & 37.04 \\
\hline Aphelochaetaundet. & 0.00 & 0.67 & 4.55 & 0.65 & 4.98 & 42.02 \\
\hline Jasmineira regularis & 0.00 & 0.33 & 4.34 & 0.58 & 4.75 & 46.78 \\
\hline Maldane sarsi antarctica & 0.55 & 0.00 & 4.31 & 0.65 & 4.72 & 51.50 \\
\hline Glycera kerguelensis & 0.45 & 0.33 & 4.09 & 0.83 & 4.48 & 55.98 \\
\hline Laonice weddellia & 0.18 & 0.33 & 3.10 & 0.72 & 3.39 & 59.38 \\
\hline Galathowenia scotiae & 0.18 & 0.33 & 3.09 & 0.66 & 3.38 & 62.76 \\
\hline Lumbrineris kerguelensis & 0.09 & 0.33 & 2.91 & 0.68 & 3.19 & 65.95 \\
\hline Thelepus cincinnatus & 0.36 & 0.00 & 2.86 & 0.45 & 3.13 & 69.08 \\
\hline Spionidae undet. & 0.09 & 0.33 & 2.75 & 0.67 & 3.01 & 72.09 \\
\hline Species & Group A1 AvAbnd & Group B AvAbnd & AvDiss & Diss/SD & Contrib\% & Cum\% \\
\hline \multicolumn{7}{|c|}{$A 1$ versus $B($ Average dissimilarity $=96.48)$} \\
\hline Rhodine intermedia & 0.00 & 17.80 & 10.93 & 0.55 & 11.33 & 11.33 \\
\hline Pista spinifera & 0.00 & 9.10 & 7.86 & 0.51 & 8.14 & 19.47 \\
\hline Artacama proboscidea & 0.00 & 6.60 & 6.11 & 0.37 & 6.33 & 25.81 \\
\hline Laonice antarcticae & 0.00 & 8.60 & 6.11 & 0.39 & 6.33 & 32.13 \\
\hline Lumbrineris kerguelensis & 0.09 & 6.40 & 5.97 & 1.15 & 6.18 & 38.32 \\
\hline Aphelochaeta cincinnata & 0.09 & 11.90 & 5.93 & 0.67 & 6.14 & 44.46 \\
\hline Axiothella antarctica & 0.00 & 5.00 & 5.74 & 0.38 & 5.95 & 50.41 \\
\hline Amphicteis gunneri antarctica & 0.09 & 5.20 & 5.20 & 0.48 & 5.39 & 55.80 \\
\hline
\end{tabular}




\begin{tabular}{|c|c|c|c|c|c|c|}
\hline Maldanidae gen. sp. & 0.09 & 5.20 & 4.76 & 0.58 & 4.93 & 60.73 \\
\hline Laonice weddellia & 0.18 & 3.00 & 3.19 & 0.71 & 3.30 & 64.04 \\
\hline Maldane sarsi antarctica & 0.55 & 2.60 & 1.91 & 1.07 & 1.98 & 66.01 \\
\hline Terebella ehlersi & 0.00 & 1.70 & 1.77 & 0.33 & 1.84 & 67.85 \\
\hline Notomastus latericeus & 1.18 & 2.10 & 1.72 & 1.00 & 1.79 & 69.64 \\
\hline Spiophanes tcherniai & 0.00 & 1.90 & 1.68 & 0.69 & 1.74 & 71.38 \\
\hline Species & Group A2 AvAbnd & Group B AvAbnd & AvDiss & Diss/SD & Contrib\% & Cum\% \\
\hline \multicolumn{7}{|c|}{$A 2$ versus $B($ Average dissimilarity $=97.90)$} \\
\hline Rhodine intermedia & 0.00 & 17.80 & 11.17 & 0.54 & 11.41 & 11.41 \\
\hline Pista spinifera & 0.00 & 9.10 & 8.05 & 0.50 & 8.22 & 19.63 \\
\hline Artacama proboscidea & 0.00 & 6.60 & 6.27 & 0.37 & 6.41 & 26.03 \\
\hline Laonice antarcticae & 0.00 & 8.60 & 6.23 & 0.38 & 6.36 & 32.39 \\
\hline Aphelochaeta cincinnata & 0.00 & 11.90 & 6.07 & 0.67 & 6.20 & 38.59 \\
\hline Lumbrineris kerguelensis & 0.33 & 6.40 & 5.93 & 1.11 & 6.06 & 44.65 \\
\hline Axiothella antarctica & 0.00 & 5.00 & 5.93 & 0.38 & 6.06 & 50.71 \\
\hline Amphicteis gunneri antarctica & 0.00 & 5.20 & 5.33 & 0.47 & 5.44 & 56.15 \\
\hline Maldanidae gen. sp. & 0.00 & 5.20 & 4.86 & 0.57 & 4.96 & 61.12 \\
\hline Laonice weddellia & 0.33 & 3.00 & 3.27 & 0.71 & 3.34 & 64.45 \\
\hline Maldane sarsi antarctica & 0.00 & 2.60 & 2.16 & 1.10 & 2.20 & 66.66 \\
\hline Terebella ehlersi & 0.00 & 1.70 & 1.82 & 0.33 & 1.86 & 68.52 \\
\hline Galathowenia scotiae & 0.33 & 1.60 & 1.74 & 0.60 & 1.77 & 70.29 \\
\hline
\end{tabular}

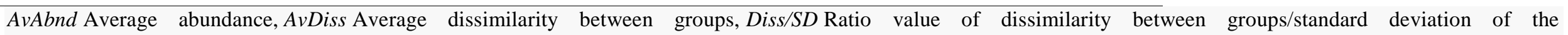
same, Contrib\% Contribution to dissimilarity between groups, Cum\% Cumulative dissimilarity between groups 
In the case of group B, although the cluster analysis brought together the two groups of geographically distant stations (AP and PI) without a clear separation between them, certain species were only present in Peter I Island, such as the terebellid Pista spinifera (PI5 and PI6), whereas the spionid Laonice weddellia (AP39) and the cirratulid Chaetozone setosa(AP21) were found exclusively in the Antarctic Peninsula. Only one station in Peter I Island (PI8) showed higher similarity with the Antarctic Peninsula stations (AP25 and AP21) than with the rest of the stations located in the vicinity of the island; this affinity was mainly due to the shared greater abundance of the maldanid Rhodine intermedia.

Three stations from west Bellingshausen Sea, BS31, BS34 and BS36, did not group into any cluster, although they were surprisingly located closer to group B (AP and PI stations) than to group A (remaining BS stations) in the plot (Fig. 4a). This fact seemed not to be related to sediment characteristics, depth or geographical position, but to the faunal composition. The few polychaete taxa identified in these samples revealed a number of species that were present only in these stations (namely G. cf. capitata, Levinsenia antarctica and Scolelepis eltaninae) as well as a number of species shared with stations of cluster B (M. sarsi, R. intermedia, L. kerguelensis, Ampharete kerguelensis and Ophelina breviata), while only one species, Aricidea(Acmira) simplex, was sheared with the samples forming the cluster A.

Depth ranges of the most abundant polychaete species are depicted in Fig. 6; most of them had a wide distribution from the upper shelf to the slope at about 2,000 $\mathrm{m}$. Only four species were not found in
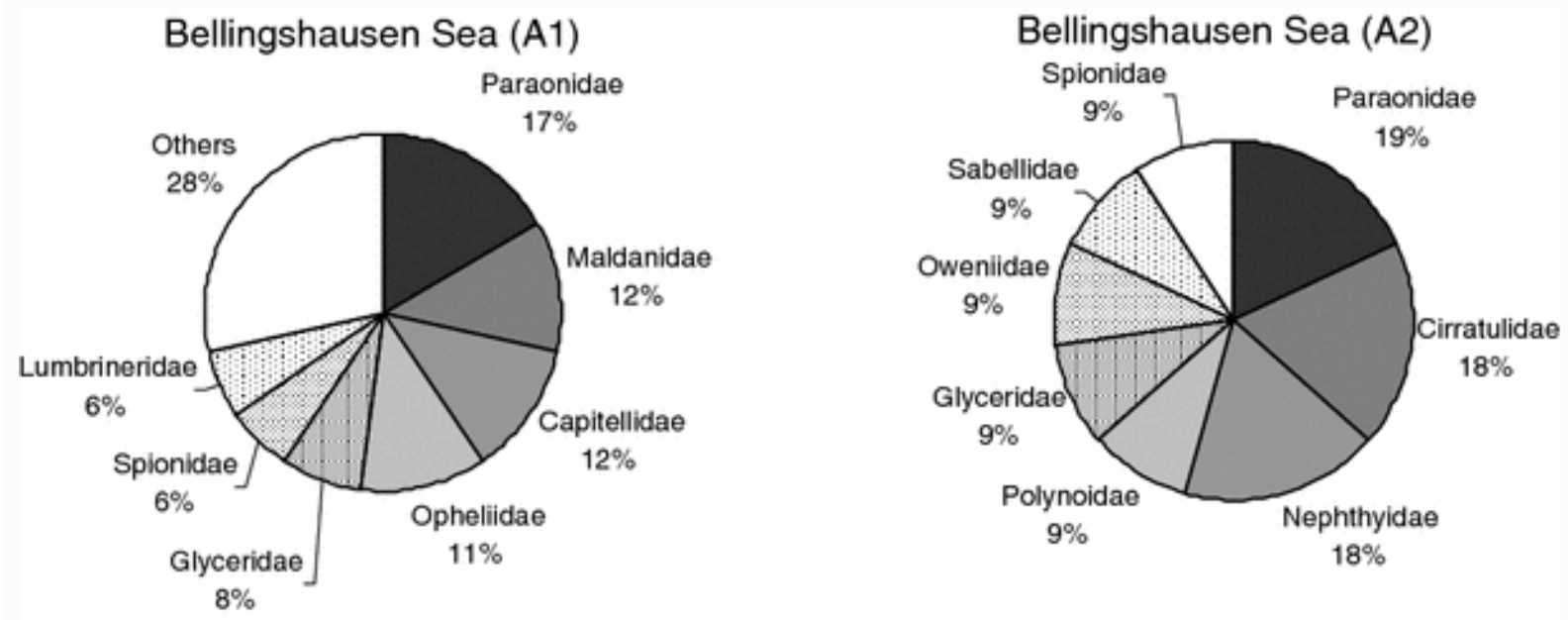

Peter I and Antarctic Peninsula (B)

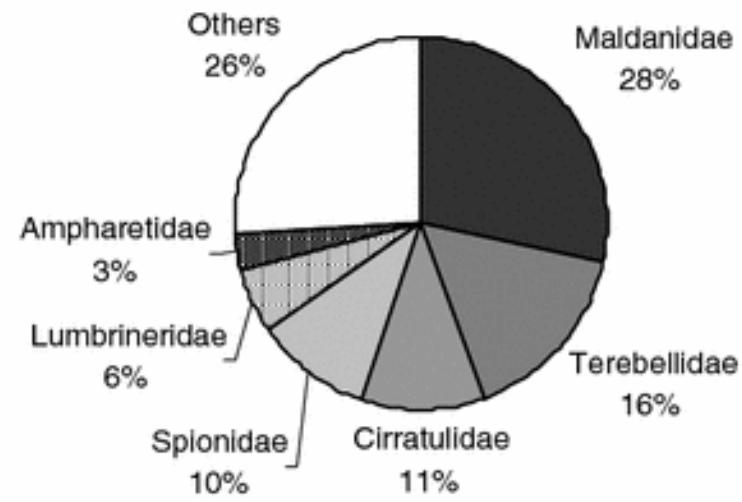

Fig. 5 Most abundant polychaete families in each group as defined by cluster analysis 
shallower waters, namely $T$. ehlersi, A. antarctica, $P$. monroi and A. (A.) belgicae, while others seemed to be limited to the shelf (i.e., $P$. spinifera, $S$. tcherniai, E. pallida, $R$. intermedia, $E$. subulifera, A. cincinnata and A. gunneri antarctica). No species had a distribution restricted to the slope (below 1,000 m depth).

Relationship between biotic and environmental variables

The first run of the BIO-ENV procedure pointed out that depth and gravel content of the sediment showed the highest correlations with faunistical data (Table 5). Thus, the three defined groups of stations could be discriminated on the basis of their abiotic conditions (Table 6), with A1 comprising deep stations from the shelf of the Bellingshausen Sea (average depth $=1,053.83 \pm 579.16 \mathrm{~m}$ ) with relatively high content of gravel in the sediment (average $=37.00 \pm 23.02 \%$ ), A2 comprising relatively shallow (average depth $=465.00 \pm 58.39 \mathrm{~m}$ ) stations from the shelf of the Bellingshausen Sea with medium gravel content in the sediment (average $=18.34 \pm 13.64 \%$ ) and B comprising stations from the vicinity of Peter I Island and off the Antarctic Peninsula, usually shallow (average depth $=322.50 \pm 326.2 \mathrm{~m}$ ) and with a low gravel content in the sediment (average $=3.44 \pm 2.86 \%$ ). The differences were statistically significant for the two variables $(P=0.003$ and $P=0.001$, respectively).

Pista spinifera
Spiophanes tchernial
Euchone pallida
Rhodine intermedia
Eulalia subulifera
Aphelochaeta cincinnatus
Amphicteis gunneri antarctica
Galathowenia scotiae
Aglaophamus trissophyllus
Lubrineris kerguelensis
Artacama proboscidea
Laonice antarcticae
Ophelina breviata
Travisia abyssorum
Jasmineira regularis
Laonice weddellia
Notomastus latericeus
Maldane sarsi antarctica
Glycera kerguelensis
Thelepus cincinnatus
Terebella ehlersi
Axiothella antarctica
Phyllochaetopterus monroi
Aricidea (Allia) belgicae
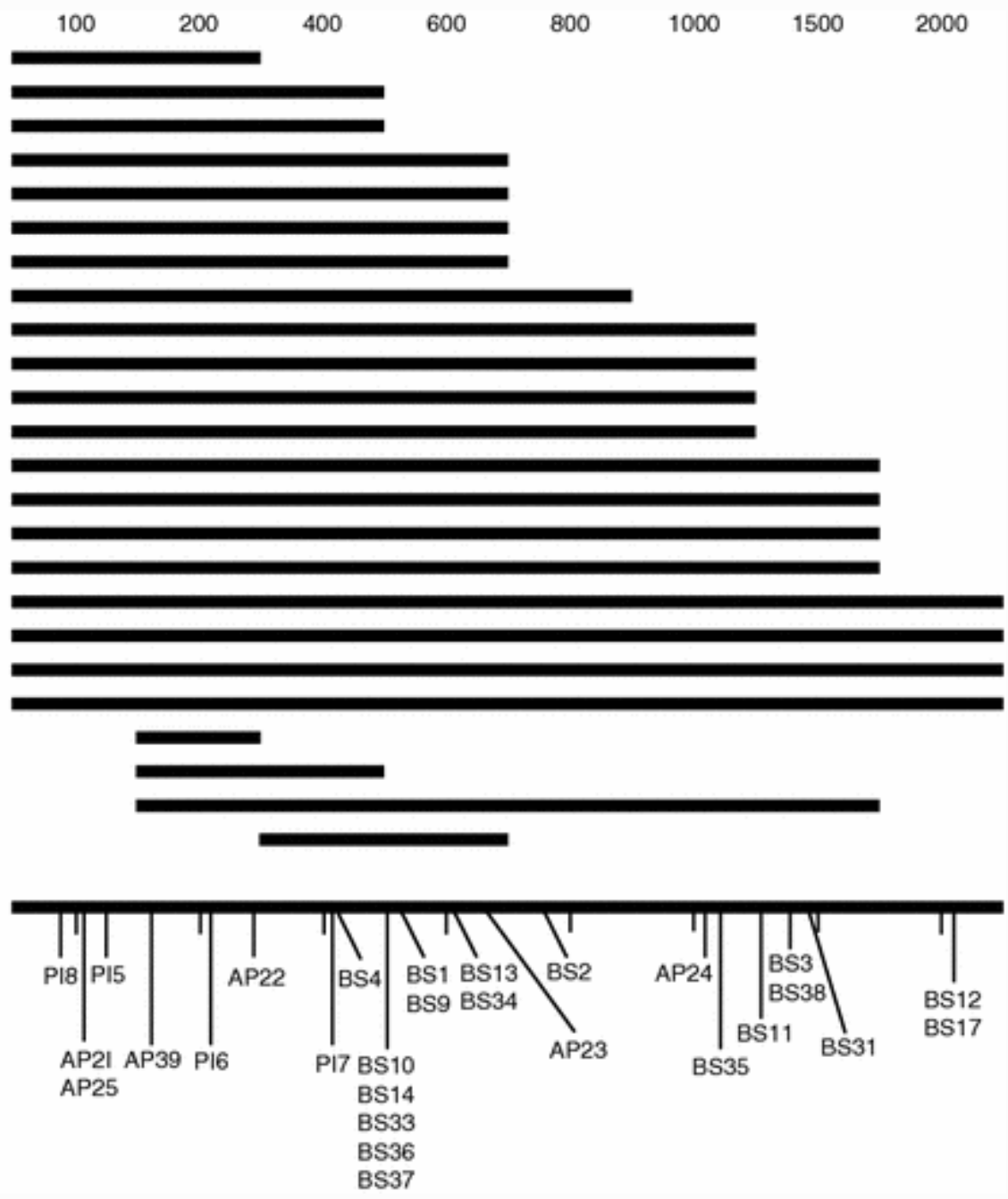

Fig. 6 Depth distribution ranges of most abundant polychaete species and position related to depth of each sampling station (bottom) 
Prior to performing the BIO-ENV analysis again considering also the redox potential, the consistency of the clusters was tested by re-analysing the data after eliminating those stations in which this variable was not measured. These new analyses gave consistent and similar outputs, this time the three previous detected groups (A1, A2 and B) being even more clearly defined. The analysis resulted in only a slight modification of internal topography in the case of the cluster analysis and a virtually identical location of samples in the nMDS plot. In the re-run of the BIO-ENV test (Table 5), depth resulted secondarily important to discriminate the station groups, whereas the redox and gravel content in the sediment became the best variable combination. The redox potential, in particular, seemed important to discriminate the groups. Thus, the average redox potential was $259.54 \pm 80.95 \mathrm{mV}$ in group A1 and $274.43 \pm 14.6 \mathrm{mV}$ in A2, while in group B, it was clearly lower $(170.74 \pm 48.20 \mathrm{mV})$, being statistically significant $(P=0.005)$.

The distribution of values of the aforementioned variables superimposed on the nMDS plot suggests the presence of an environmental gradient in the studied area (Fig. 4b-d). This gradient involved gravel content, redox potential at the sediment surface and depth and it is characterized by more oxidized sediments with higher contents of gravel at the deeper stations, which are represented at the left part of the plot while the other stations are placed on the opposite side.

Table 5 Best combinations of variables obtained through BIO-ENV analysis according to the values of the Spearman rank correlation $\left(p_{\mathrm{w}}\right)$

\begin{tabular}{ll}
\hline Correlation $\left(\boldsymbol{p}_{\mathbf{w}}\right)$ & Variable combination \\
\hline All stations considered; redox excluded \\
0.314 & Depth, gravel \\
0.294 & Depth, gravel, fine sand \\
0.293 & Depth, gravel, coarse sand \\
0.288 & Depth, gravel, medium sand \\
0.286 & Depth, organic matter, gravel \\
0.285 & Gravel, mud \\
0.281 & Gravel, fine sand \\
0.280 & Gravel, coarse sand, mud \\
0.276 & Depth, gravel, mud \\
0.276 & Gravel, medium sand, mud \\
Redox considered; BS14 \& AP25 excluded \\
0.326 & Redox, gravel \\
0.315 & Redox, gravel, coarse sand \\
0.310 & Depth, redox, gravel \\
0.307 & Redox, gravel, mud \\
0.301 & Redox, organic matter, gravel \\
0.300 & Depth, redox, gravel, mud \\
0.300 & Redox, gravel, medium sand \\
0.296 & Gravel, mud \\
0.294 & Depth, gravel \\
0.291 & Depth, gravel, mud \\
\hline
\end{tabular}


Table 6 Mean values and standard deviations for environmental and ecological parameters at the stations within the groups identified by the Bray -Curtis similarity analysis

\begin{tabular}{|c|c|c|c|c|c|c|c|c|c|c|c|c|c|}
\hline Cluster & Depth & Redox & OM & Gravel & CS & MS & FS & Mud & $S$ & $N$ & $d$ & $\boldsymbol{H}^{\prime}$ & $J^{\prime}$ \\
\hline A1 & $1053.83 \pm 579.16$ & $259.54 \pm 80.95$ & $4.81 \pm 1.36$ & $37.00 \pm 23.02$ & $7.51 \pm 5.48$ & $4.54 \pm 2.83$ & $13.25 \pm 8.08$ & $37.72 \pm 17.60$ & $6.08 \pm 3.20$ & $8.17 \pm 5.24$ & $2.46 \pm 0.78$ & $1.58 \pm 0.55$ & $0.96 \pm 0.04$ \\
\hline A2 & $465.00 \pm 58.39$ & $274.43 \pm 14.46$ & $4.85 \pm 1.00$ & $18.34 \pm 13.64$ & $9.56 \pm 3.45$ & $6.22 \pm 2.34$ & $18.37 \pm 7.17$ & $47.51 \pm 22.44$ & $4.67 \pm 2.52$ & $5.33 \pm 3.06$ & $2.19 \pm 0.73$ & $1.39 \pm 0.63$ & $0.98 \pm 0.02$ \\
\hline B & $322.50 \pm 312.37$ & $170.74 \pm 48.20$ & $3.44 \pm 2.86$ & $3.16 \pm 7.87$ & $4.41 \pm 8.44$ & $4.22 \pm 6.77$ & $20.95 \pm 19.27$ & $67.28 \pm 35.37$ & $18.20 \pm 10.54$ & $118.40 \pm 72.14$ & $3.61 \pm 1.85$ & $1.97 \pm 0.61$ & $0.71 \pm 0.13$ \\
\hline
\end{tabular}

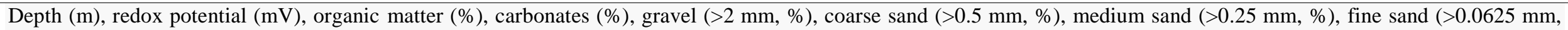

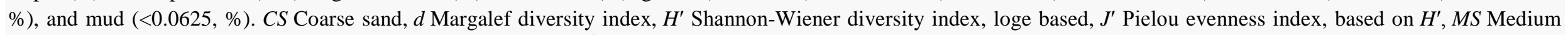
sand, FS Fine sand, $N$ Number of specimens collected in $1,890 \mathrm{~cm}^{2}, S$ Number of species and $O M$ Organic matter 


\section{Discussion}

Since Hartman's contributions to the taxonomy of Antarctic polychaetes in the fifties and sixties of twentieth century (e.g., Hartman 1952, 1953, 1964, 1966, 1967), much effort has been made by many authors to increase the knowledge of this taxon, especially in the late eighties (e.g., HartmannSchröder and Rosenfeldt 1988, 1989, 1990, 1991, 1992) and in more recent years (e.g., Hilbig 2004; Schüller and Ebbe 2007; Schüller and Hilbig 2007; Schüller 2008a, b; Schüller et al. 2009). Nevertheless, apart from papers by Hartman (1978) and Knox and Cameron (1998) devoted to the Weddell and Ross Seas, respectively, there are no recent monographs that compile this information and much work is still necessary to shade light in many polychaete taxa still poorly known. For example, the genus Ampharete Malmgren, 1866 is among the most species-rich genera in boreo-arctic waters, with eight species described or reported to date (Holthe 1986; Jirkov 2001), while in Antarctic waters is represented by just a single species: Ampharete kerguelensis McIntosh, 1885 (see Schüller 2008a). In addition, we agree with Gambi and Mariani (1999), who stated that many of the northern species traditionally reported in austral waters (e.g., $P$. cristata, $T$. cincinnatus, $N$. latericeus and $C$. cirratus) probably represent new species, as has already been reported for some taxa belonging to Scalibregmatidae (Blake 1981), Oweniidae (Blake 1984; Parapar 2003), Melinninae (Parapar and San Martín 1997), Sabellidae (Giangrande and Gambi 1997), Opheliidae (Maciolek and Blake 2006) and Trichobranchidae (Parapar and Moreira 2008). These current limitations in the knowledge of the polychaete taxonomy of the Southern Ocean limit in certain way the quality of the catalogue of species presented here, which in spite of certain lack of definition in the identification in some taxa, comes to fill anyway an important emptiness in the knowledge of the polychaete fauna in the Bellingshausen Sea.

From the analysis of the list of species obtained, two main groups of stations could be defined. On the one hand, most of the stations from the Bellingshausen Sea determined the group A, which could, in turn, be divided into groups A1 and A2; on the other hand, the stations from off the Antarctic Peninsula, Gerlache Strait and the vicinity of Peter I Island formed group B, even though geographically Peter I belongs to the Bellingshausen Sea. Groups A and B showed sharp differences in their polychaete species composition as well as in abundance and number of species which were noticeably higher in stations of group B. There were differences in the mean values of diversity indexes as well they were, however, not significant.

When environmental variables were considered, stations of group A were characterized by higher redox potential and gravel content in the sediment than those of group B. In turn, the two sub-groups within group A (A1 and A2) showed environmental differences related to depth, with group A1 representing deeper stations. The stations included within group B were usually located at relatively shallow depths.

From the present data, it can be concluded that the polychaete faunas of the Antarctic Peninsula and the Bellingshausen Sea (except for those from the vicinity of Peter I Island) are clearly different. Our results referred to the Antarctic Peninsula did not differ substantially from those previously recorded for the area (San Martín et al. 2000), reporting again Maldanidae, Terebellidae and Cirratulidae as the most abundant families. However, Hilbig et al. (2006) did not find such high abundances for Terebellidae in the Weddell Sea, while Terebellidae are among the most speciose family in the Ross Sea (Cantone et al. 2000; Cigliano and Gambi unpublished data). At the species level, all the characteristic taxa herein recorded were mentioned as such by the above-mentioned authors; this situation suggests that most of the polychaete fauna reported from the Antarctica has a wide distribution through the Southern Ocean. Hilbig (2004) noticed these patterns, suggesting that they 
reflect the persistence of a pre-existing polychaete fauna around Antarctica related to the establishment of the circum-Antarctic current in the past coupled with the characteristically high physiological flexibility of these animals.

Interestingly, in spite of the remoteness of this island placed nearly in the middle of the Bellingshausen Sea, the stations located around Peter I Island harboured polychaete assemblages more similar to those found off the Antarctic Peninsula than to those typical of the shelf of Bellingshausen Sea. This parallelism might be, at least in part, due to the presence of the same kind of gravel-free sediment which revealed the absence of stones in the sediment surface. These stones are much more abundant in many of the BS stations, as already reported by Saiz et al. (2008), and are brought by icebergs on their journey from the continent, falling to the bottom as a result of the melting process of the ice. In addition, the disturbance created on the seabed by the iceberg scouring could be the cause of some environmental changes that would result in a different specific composition in the stations of cluster A. In fact, there were three stations at western central Bellingshausen Sea which were left out of the main groupings and were located closer to cluster B; this may highlight a greater stability of the sediment as suggested by the presence of maldanids, which are also typical from this group. On the contrary, group A has sediments disturbed by the action of iceberg scouring and therefore has a fauna dominated by polychaetes of short life cycle, such as capitellids and paraonids.

In contrast to the waters around the Antarctic Peninsula, the Bellingshausen Sea has been little investigated to date due to the prevalence of ice for most of the year (Clarke and Johnston 2003; Linse et al. 2006); thus, our results cannot be compared with previous quantitative studies on the area. A short list of species from Peter I island was provided by Hartman (1967), and some observations on general benthos (not including polychaetes) have been done with remote sensing ROV (Gutt et al. 1996). However, when most characteristic species are considered, differences arise not only with the Antarctic Peninsula but also with adjacent areas such as the Weddell Sea (Hilbig et al. 2006), in which the amphinomid Paramphinome australis and the cirratulids Monticellina sp. and Chaetozone sp. were the most characteristic species in open sea stations, or the Ross Sea, in which Terebellidae was the most species-rich family (Cantone et al.2000; Cantone and di Pietro 2001; Cigliano and Gambi unpublished data). The noticeably low values for abundance and diversity herein found were previously reported for comparably deep stations from the Weddell Sea (Hilbig 2001), although in this region the number of species tended to be quite high.

From these results, it seems that the Bellingshausen Sea constitutes to some extent a differentiated area in the Southern Ocean, pointing to a well-defined biogeographical region, as proposed by Clarke et al. (2004). Other researches conducted with molluscs collected during the expeditions BENTART 2003 and 2006 also showed similar results (Troncoso et al. 2007; Troncoso and Aldea 2008). At higher levels of taxonomic resolution, Saiz et al. (2008) described benthic assemblages characterized by low values of abundance and diversity and constituted by impoverished faunas dominated by foraminiferans, which caused the region to be described as a "benthic desert". This paucity of species and individuals might be linked in part to the particular sediment composition of the shelf in Bellingshausen Sea, which is defined by foraminifer-bearing, opal-free sediments in the west of the region and diatom-bearing, carbonate-free in the east (Hillenbrand et al. 2003).

From our results, it could be inferred that sediment characteristics, followed by depth, were the main environmental variables determining the structure of polychaete assemblages in the Bellingshausen Sea and nearby areas of the Antarctic Peninsula. However, other studies undertook in the same area and devoted to other taxa found depth as having greater importance than sediment features 
(Matallanas and Olaso 2007; Troncoso et al. 2007, 2008; Saiz et al. 2008); some of the sediment features (namely redox potential and mud content) were, however, found to act combined to depth in determining suprabenthic community structure (San Vicente et al. 2009). In fact, the identity of the most important environmental variables determining benthic communities in the Southern Ocean is still a matter of discrepancy. Apart of the above-commented iceberg scouring, which is a major source of disturbance at both shallow waters and shelf and slope depths (Gutt and Starmans 2001), depth has been traditionally considered a major factor determining the structure of these communities (Arntz et al. 1994), probably due to the limited organic input received by deeper bottoms (Smith et al. 2006). This scheme has recently been challenged (Gutt and Starmans 1998; Gutt 2000), proposing the bottom-near currents as being the main "driving force" for Antarctic benthic communities. Our results cannot directly provide support for any of the proposed models, since depth showed a less important correlation with faunal data in the two environmental analyses performed. In fact, our analyses revealed that sediment features such as redox potential or gravel content showed more relevance than depth itself. Recent studies in the Weddell Sea by Schüller et al. (2009) also point to sediment characteristics to be more important than depth in structuring soft-bottom polychaete communities. Those features might be directly linked to the current system near the bottom, thus suggesting that a process more complex than depth-related organic input is responsible for the faunistical composition of the benthic communities inhabiting the shelf of Bellingshausen Sea.

In short, the results of this quantitative study of the polychaetes of the Bellingshausen Sea, although largely limited by the sample size that makes the conclusions to be taken with caution, suggest extreme differences in the biological parameters within the area studied. Thus, the stations off the Antarctic Peninsula and Peter I Island showed much more abundant and diverse polychaete communities than those of the Bellingshausen Sea. These differences appear to be related both to depth as to the characteristics of the sediment and probably the important role played by the intense traffic of icebergs in the area, with its plowing affect on the seabed, creates significant physical disturbance in the ecosystem by limiting the establishment of stable communities over the time.

\section{Acknowledgments}

The present study was financially supported by the Spanish Ministerio de Ciencia y Tecnología through the research projects "Estudio integrado de la biodiversidad bentónica del mar de Bellingshausen y península Antártica (Antártida del Oeste). Primera campaña de muestreo a bordo del B/O Hespérides (REN2001-1074/ANT)" and "Estudio integrado de la biodiversidad bentónica del mar de Bellingshausen y península Antártica. Segunda campaña de muestreo a bordo del B/O Hespérides (CGL2004/01856)". The authors wish to express their gratitude to C. Aldea (UVigo, Spain) for the elaboration of the map, to J. Moreira (USC, Spain) for the identification of the Sphaerodorid species and comments on an earlier version of the manuscript and to the colleagues of the BENTART project and to the crew of R/V Hespérides, for their collaboration onboard the ship. We thank also Brigitte Ebbe (Senckenberg Institut, Germany), Myriam Schüller (Ruhr-Universität Bochum, Germany) and a third anonymous referee for their helpful comments concerning the manuscript. The help of Greg Rouse (Scripps Institution of Oceanography, USA) improving the English in an earlier version of the manuscript is also appreciated. 


\section{References}

Arnaud PM (1974) Contribution a la bionomie benthique des régions antarctiques et subantarctiques. Téthys 6:465-656

Arntz WE, Brey T, Gallardo VA (1994) Antarctic Zoobenthos. Oceanogr Mar Biol Ann Rev 32:241304

Arrigo KR, Worthen D, Schnell AM, Lizotte MP (1998) Primary production in Southern Ocean waters. J Geophys Res 103:15-587-15-600

Augener H (1932) Antarktische und Antiboreale Polychaeten nebst einer Hirudinee. Scientific results of the Norwegian Antarctic expedition, 1927-28. Nor Vid Akad Oslo 9:1-86

Blake J (1981) The Scalibregmatidae (Annelida: Polychaeta) from South America and Antarctica collected chiefly during the cruises of the R/V Anton Brunn, R/V Hero and USNS Eltanin. Proc Biol Soc Wash 94:1131-1162

Blake J (1984) Polychaeta Oweniidae from Antarctic seas collected by The United States Antarctic research program. In: En Hutchings PA (ed) Proceeding of the first international polychaete conference, Sydney, Australia. Linn Soc New S Wales, Sydney, pp 112-117

Brandt A, De Broyer C, Gooday AJ, Hilbig B, Thomson MRA (2004) Introduction to ANDEEP (ANtarctic benthic DEEP-sea biodiversity: colonization history and recent community patterns)a tribute to Howard L. Sanders. Deep Sea Res II 51:1457-1465

Cantone G, di Pietro N (2001) Benthic littoral Polychaeta "Sedentaria" of Terra Nova Bay (Ross Sea, Antarctica). Antarct Sci 13:3-8

Cantone G, Castelli A, Gambi MC (2000) Benthic polychaetes off Terranova Bay and Ross Sea: species composition, biogeography and ecological role. In: Faranda FM, Guglielmo L, Ionora A (eds) Ross sea ecology. Springer, Berlin

Clarke A, Johnston NM (2003) Antarctic marine benthic diversity. Oceanogr Mar Biol Ann Rev 41:47-114

Clarke KR, Warwick RM (1994) Changes in marine communities: an approach to statistical analysis and interpretation. Natural Environmental Research Council, Plymouth

Clarke A, Aronson RB, Crame JA, Gili JM, Blake DB (2004) Evolution and diversity of the benthic fauna of the Southern Ocean continental shelf. Antarct Sci 16:559-568

Corbera J, San Vicente C, Sorbe J-C (2009) Cumaceans (Crustacea) from the Bellingshausen sea and off the western Antarctic Peninsula: deep-water link with fauna of the surrounding oceans. Polar Biol 32:611-622

Fauvel P (1936) Polychètes de l'expédition antarctique Belgica. Résultats du voyage de la Belgica en 1897-1899 sur le commandement de A. de Gerlache de Gomery. Buschmann, Anverns

Gambi MC, Mariani S (1999) Polychaetes of the soft bottoms of the Strait of Magellan collected during the Italian oceanographic cruise in February-March 1991. Sci Mar 63:233-242

Gerdes D, Klages M, Arntz WE, Herman RL, Galéron J, Hain S (1992) Quantitative investigations on macrobenthos communities of the southwestern Weddell Sea shelf based on multibox corer samples. Polar Biol 12:291-301

Giangrande A, Gambi MC (1997) The genus Perkinsiana (Polychaeta, Sabellidae) from Antarctica, with descriptions of the new species P. milae and P. borsbrunoi. Zool Scr 26:267-278

Gray JS (1974) Animal-sediment relationships. Oceanogr Mar Biol Ann Rev 12:223-261

Grebmeier J, Barry J (1991) Influence of oceanographic processes on pelagic-benthic coupling in Polar regions: a benthic perspective. J Mar Syst 2:495-518

Guglielmo L, Carrada GC, Catalano G, Dell'Anno A, Fabiano M, Lazzara L, Mangoni O, Pusceddu A, Saggiomo V (2000) Structural and functional properties of sympagic communities in the annual sea ice at Terra Nova Bay (Ross Sea, Antarctica). Polar Biol 23:137-146

Gutt J (2000) Some "driving forces" structuring communities of the sublittoral Antarctic macrobenthos. Antarct Sci 12:297-313

Gutt J (2001) On the direct impact of ice on marine benthic communities, a review. Polar Biol 24:553-564

Gutt J, Piepenburg D (2003) Scale-dependent impact on diversity of Antarctic benthos caused by grounding of icebergs. Mar Ecol Progr Ser 253:77-83 
Gutt J, Starmans A (1998) Structure and biodiversity of megabenthos in the Weddell and Lazarev Seas (Antarctica): ecological role of physical parameters and biological interactions. Polar Biol 20:229-247

Gutt J, Starmans A (2001) Quantification of iceberg impact and benthic recolonisation patterns in the Weddell Sea (Antarctica). Polar Biol 24:615-619

Gutt J, Starmans A, Dieckmann D (1996) Impact of iceberg scouring on polar benthic habitats. Mar Ecol Progr Ser 137:311-316

Hartman O (1952) The marine annelids of the U. S. Navy Antarctic expedition 1947-48. J Wash Acad Sci 42:231-237

Hartman O (1953) Non-pelagic polychaeta of the Swedish Antarctic expedition 1901-1903. Further Zool Res Swed Ant Exp 1901-1903 4:1-83

Hartman O (1964) Polychaeta Errantia of Antarctica. Antarct Res Ser 3:1-131

Hartman O (1966) Polychaeta Myzostomida and sedentaria of Antarctica. Antarct Res Ser 7:1-158

Hartman O (1967) Polychaetous annelids collected by the USNS Eltanin and Staten Islandscruises, chiefly from Antarctic Seas. Allan Hancock Monogr Mar Biol 2:1-387

Hartman O (1978) Polychaeta from the Weddell Sea quadrant, Antarctica. Allan Hancock Foundation, Los Angeles

Hartmann-Schröder G, Rosenfeldt P (1989) Die Polychaeten der „Polarstern"-Reise ANT III/2 in die Antarktis 1984. Teil 2. Cirratulidae bis Serpulidae. Mitt Hamb Zool Mus Inst 86:65-106

Hartmann-Schröder G, Rosenfeldt P (1991) Die Polychaeten der „Walter Herwig“-Reise 68/1 nach Elephant Island (Antarktis) 1985. Teil 2. Acrocirridae bis Sabellidae. Mitt Hamb Zool Mus Inst 88:73-96

Hartmann-Schröder G, Rosenfeldt P (1988) Die Polychaeten der „Polarstern"-Reise ANT III/2 in die Antarktis 1984. Teil 1. Euphrosinidae bis Chaetopteridae. Mitt Hamb Zool Mus Inst 85:25-72

Hartmann-Schröder G, Rosenfeldt P (1990) Die Polychaeten der „Walther Herwig“-Reise 68/1 nach Elephant Island (Antarktis) 1985. Teil 1. Aphrodtidae bis Cirratulidae. Mitt Hamb Zool Mus Inst $87: 89-122$

Hartmann-Schröder G, Rosenfeldt P (1992) Die Polychaeten der „Polarstern"-Reise ANT 5/1 in die Antarktis 1986. Teil 1. Euphrosinidae bis Iphitimidae. Mitt Hamb Zool Mus Inst 89:85-124

Hilbig B (2001) Deep-sea polychaetes in the Weddell Sea and the Drake Passage: first quantitative results. Polar Biol 24:538-544

Hilbig B (2004) Polychaetes of the deep Weddell and Scotia Seas - composition and zoogeographical links. Deep Sea Res (II) 51:1817-1825

Hilbig B, Gerdes D, Montiel A (2006) Distribution patterns and biodiversity in polychaete communities of the Weddell Sea and Antarctic Peninsula area (Southern Ocean). J Mar Biol Ass UK 86:711-725

Hillenbrand C-D, Grobe H, Diekmann B, Kuhn G, Fütterer DK (2003) Distribution of clay minerals and proxies for productivity in surface sediments of the Bellingshausen and Amundsen seas (West Antarctica) - relation to modern environmental conditions. Mar Geol 193:253-271

Holthe T (1986) Polychaeta Terebellomorpha. Mar Invertebr Scandinavia 7:1-192

Jirkov I (2001) Polychaeta of the Arctic Ocean. Yanus-K, Moskva

Knox GA (2007) The biology of the Southern Ocean. CRC Press, Florida

Knox GA, Cameron DB (1998) The marine fauna of the Ross Sea: Polychaeta. NIWA Biodivers Memoir 108:1-125

Linse K, Griffiths HJ, Barnes DKA, Clarke A (2006) Biodiversity and biogeography of Antarctic and sub-Antarctic mollusca. Deep Sea Res (II) 35:985-1008

Maciolek N, Blake JA (2006) Opheliidae (Polychaeta) collected by the R/V Hero and the USNS Eltanin cruises from the Southern Ocean and South America. Sci Mar 70:101-113

Matallanas J, Olaso I (2007) Fishes of the Bellingshausen Sea and Peter I Island. Polar Biol 30:333341

Parapar J (2003) Two new species of Myriochele (Polychaeta: Oweniidae) from the Bransfield Strait (Antarctica). Antarc Sci 15:219-226

Parapar J, Moreira J (2008) Redescription of Terebellides kerguelensis stat. nov. (Polychaeta: Trichobranchidae) from Antarctic and subantarctic waters. Hel Mar Res 62:143-152

Parapar J, San Martín G (1997) "Sedentary" polychaetes of the Livingston Island shelf (South Shetland Islands, Antarctica), with the description of a new species. Polar Biol 17:502-514 
Piepenburg D, Schmid MK, Gerdes D (2002) The benthos off King George Island (South Shetland Islands, Antarctica): further evidence for a lack of a latitudinal biomass cline in the Southern Ocean. Polar Biol 25:146-158

Rhoads DC (1974) Organisms-sediment relations on the muddy sea floor. Oceanogr Mar Biol Ann Rev 12:263-300

Saiz JI, García FJ, Manjón-Cabeza ME, Parapar J, Peña-Cantero A, Saucède T, Troncoso J, Ramos A (2008) Community structure and spatial distribution of benthic fauna in the Bellingshausen Sea (West Antarctica). Polar Biol 31:735-743

Saiz-Salinas JI, Ramos A, García FJ, Troncoso JS, San Martín G, Sanz C, Palacín C (1997) Quantitative analysis of macrobenthic soft-bottom assemblages in South Shetland waters (Antarctica). Polar Biol 17:393-400

San Martín G, Parapar J (1997) "Errant" polychaetes of the Livingston Island shelf (South Shetland Islands, Antarctica), with the description of a new species. Polar Biol 17:285-295

San Martín G, Parapar J, García FJ, Redondo MS (2000) Quantitative analysis of soft bottoms infaunal macrobenthic polychaetes from South Shetland Islands (Antarctica). Bull Mar Sci 67:83102

San Vicente C, Munilla T, Corbera J, Sorbe J-C, Ramos A (2009) Suprabenthic fauna from the Bellingshausen Sea and western Antarctic Peninsula; spatial distribution and community structure. Sci Mar 73:357-368

Schüller M (2008a) New polychaete species collected during the expeditions ANDEEP I, II, and III to the deep Atlantic sector of the Southern Ocean in the Austral summers 2002 ND 2005Ampharetidae, Opheliidae, and Scalibregmatidae. Zootaxa 1705:51-68

Schüller M (2008b) Polychaeta (Annelida) of the Southern Ocean. Biodiversity and zoogeography. VDM Verlag Dr. Müller

Schüller M, Ebbe B (2007) Global distribution patterns of selected deep-sea Polychaeta (Annelida) from the Southern Ocean. Deep Sea Research II 54:1737-1751

Schüller M, Hilbig B (2007) Three new species of the genus Oligobregma (Polychaeta, Scalibregmatidae) from the Scotia and Weddell Seas (Antarctica). Zootaxa 1391:35-45

Schüller M, Ebbe B, Wägele J-W (2009) Community structure and diversity of polychaetes (Annelida) in the deep Weddell Sea (Southern Ocean) and adjacent basins. Mar Biodivers 39:95108

Smale DA (2008a) Continuous benthic community change along a depth gradient in Antarctic shallows: evidence of patchiness but not zonation. Polar Biol 31:189-198

Smale DA (2008b) Ecological traits of benthic assemblages in shallow Antarctic waters: does ice scour disturbance select for small, mobile, secondary consumers with high dispersal potential? Polar Biol 31:1225-1231

Smale DA, Barnes DKA, Fraser KPP (2007) The influence of depth, site exposure and season on the intensity of iceberg scouring in nearshore Antarctic waters. Polar Biol 30:769-779

Smith CR, Minks S, De Master DJ (2006) A synthesis of bentho-pelagic coupling on the Antarctic shelf: food banks, ecosystem inertia and global climate change. Deep Sea Res (II) 53:875-894

Troncoso JS, Aldea C (2008) Macrobenthic mollusc assemblages and diversity in the West Antarctica from the South Shetland Islands to the Bellingshausen Sea. Polar Biol 31:1253-1265

Troncoso JS, Aldea C, Arnaud P, Ramos A, García F (2007) Quantitative analysis of soft-bottom molluscs in the Bellingshausen Sea and around Peter I Island. Polar Res 26:126-134

Wu B, Chen M, Wu Q, Huan F (1992a) A study on the quantity of shallow sea benthos in the Great Wall Bay, Antarctica. Antarct Res/Nanji Yanjiu 4:55-61

Wu Q, Wu B, Chen M, Huan F (1992b) Community analysis of shallow sea benthos in the Great Wall Bay, Antarctica. Antarct Res/Nanji Yanjiu 4:62-67 


\section{Appendix}

Table 7 Polychaete species identified from the box-corer samples in the BENTART-2003 and 2006 cruises in the Bellingshausen Sea and Gerlache Strait

\begin{tabular}{|c|c|}
\hline Ampharetidae & Oweniidae \\
\hline Amphicteis gunneri antarctica Hessle, 1917 & Galathowenia scotiae (Hartman, 1978) \\
\hline Amythas membranifera Benham, 1921 & Oweniidae gen. sp. \\
\hline Ampharete kerguelensis McIntosh, 1885 & Paraonidae \\
\hline Ampharete sp. & Aricidea (Acmira) simplex Day, 1963 \\
\hline Phyllocomиs crocea Grube, 1877 & Levinsenia antarctica Strelzov, 1963 \\
\hline Ampharetidae gen. sp. & Cirrophorus brevicirratus Strelzov, 1973 \\
\hline Amphinomidae & Aricidea (Allia) belgicae (Fauvel, 1936) \\
\hline Paramphinome australis Monro, 1930 & Phyllodocidae \\
\hline Capitellidae & Anaitides adarensis (Benham, 1927) \\
\hline Capitella perarmata (Gravier, 1911) & Phyllodoce sp. \\
\hline Notomastus latericeus Sars, 1850 & Eulalia subulifera Ehlers, 1897 \\
\hline Chaetopteridae & Polynoidae \\
\hline Phyllochaetopterus monroi Hartman, 1967 & Barrukia cristata (Willey, 1902) \\
\hline Cirratulidae & Barrukia curviseta (Monro, 1930) \\
\hline Aphelochaeta cincinnata (Ehlers, 1908) & Harmothoe cf. acuminata Willey, 1902 \\
\hline Aphelochaeta epitoca (Monro, 1930) & Harmothoe exanthema bergstromi Monro, 1936 \\
\hline Aphelochaeta fusiformis (Monro, 1939) & Harmothoe undet. \\
\hline Aphelochaeta undet. & Harmothoe spinosa Kinberg, 1865 \\
\hline Chaetozone setosa Malmgren, 1867 & Sabellidae \\
\hline Cirratulus cirratus (Müller, 1776) & Demonax polarsterni Gambi et al., 2001 \\
\hline Cirratulidae undet. & Euchone pallida Ehlers, 1908 \\
\hline Eunicidae & Euchone scotiarum Hartman, 1978 \\
\hline Eunice antarctica Baird, 1869 & Jasmineira regularis Hartman, 1978 \\
\hline Flabelligeridae & $\begin{array}{l}\text { Perkinsiana } \\
\text { Gambi 1997) }\end{array}$ \\
\hline Pherusa sp. & Sabellidae undet. \\
\hline Brada villosa (Rathke, 1843) & Scalibregmatidae \\
\hline Glyceridae & Scalibregma inflatum Rathke, 1843 \\
\hline Glycera cf. capitata Ørsted, 1843 & Scalibregma sp. \\
\hline Glycera kerguelensis McIntosh, 1885 & Sclerocheilus minutus Grube, 1863 \\
\hline Glycera undet. & Serpulidae \\
\hline Lumbrineridae & Serpula narconensis Baird, 1865 \\
\hline Augeneria tentaculata Monro, 1930 & Vermiliopsis nigropileata (Ehlers, 1900) \\
\hline Lumbrineris kerguelensis (Grube, 1878) & Spirorbis nordenskjoldi Ehlers, 1900 \\
\hline Lumbrineris sp. & Sphaerodoridae \\
\hline Paraninoe antarctica (Monro, 1930) & Sphaerodoropsis cf. parva (Ehlers, 1913) \\
\hline Maldanidae & Spionidae \\
\hline Axiothella antarctica Monro, 1930 & Laonice antarcticae Hartman, 1953 \\
\hline Asychis amphiglyptus (Ehlers, 1897) & Laonice weddellia Hartman, 1978 \\
\hline Maldane sarsi antarctica Arwidsson, 1911 & Laonice sp. \\
\hline Lumbriclymenella robusta Arwidsson, 1911 & Scolelepis eltaninae Blake, 1983 \\
\hline Nicomache sp. & Spiophanes soderstromi Hartman, 1953 \\
\hline Rhodine intermedia Arwidsson, 1911 & Spiophanes tcherniai Fauvel, 1951 \\
\hline Isocyrrus yungi Gravier, 1911 & Spionidae undet. \\
\hline Nephthyidae & Sternaspidae \\
\hline Aglaophamus trissophyllus (Grube, 1877) & Sternaspis scutata (Renier, 1807) \\
\hline Nereididae & Syllidae \\
\hline
\end{tabular}




\begin{tabular}{|c|c|}
\hline Neanthes kerguelensis (McIntosh, 1885) & Exogone heterosetosa McIntosh, 1885 \\
\hline Nereis eugeniae (Kinberg, 1866) & Pionosyllis dionisi Núñez and San Martín, 1991 \\
\hline Onuphidae & Pionosyllis kerguelensis (McIntosh, 1885) \\
\hline Leptoecia benthaliana (McIntosh, 1885) & Salvatoria rhopalophora (Ehlers, 1897) \\
\hline Opheliidae & Syllis sclerolaema Ehlers, 1901 \\
\hline Ophelina breviata (Ehlers, 1913) & Terebellidae \\
\hline Travisia abyssorum (Monro, 1930) & Artacama proboscidea Malmgren, 1865 \\
\hline Opheliidae gen. sp. & Pista cristata (Müller, 1776) \\
\hline Orbiniidae & Pista corrientis McIntosh, 1885 \\
\hline Leitoscoloplos kerguelensis (McIntosh, 1885) & Pista spinifera (Ehlers, 1908) \\
\hline Leitoscoloplos mawsoni Benham, 1921 & Terebella ehlersi Gravier, 1907 \\
\hline Scoloplos (Leodamas) marginatus (Ehlers, 1897) & Thelepus cincinnatus (Fabricius, 1780) \\
\hline \multirow{3}{*}{$\begin{array}{l}\text { Phylo minima (Hartmann-Schröder and } \\
\text { Rosenfeldt, 1990) }\end{array}$} & Trichobranchidae \\
\hline & \\
\hline & Terebellides kerguelensis McIntosh, 1885 \\
\hline
\end{tabular}

